\title{
Parallel operation of current-source inverter for low-voltage high-current grid-connected photovoltaic system
}

\author{
Suroso $^{1}$, Daru Tri Nugroho ${ }^{2}$, Amran $^{3}$, Toshihiko Noguchi ${ }^{4}$ \\ 1,2,3 Department of Electrical Engineering, Jenderal Soedirman University, Indonesia \\ ${ }^{4}$ Department of Engineering, Electric and Electronics Engineering Course, Shizuoka University, Japan
}

\begin{abstract}
Article Info
Article history:

Received Jun 7, 2018

Revised Mar 13, 2019

Accepted Mar 22, 2019

Keywords:

Harmonics

Inverter

Photovoltaics

Power grid

ABSTRACT

Solar energy is very potential to be developed in a tropical country such as in Indonesia. This energy source is eco-friendly because it can eliminate air pollution such as caused by conventional fossil fuels. This research article presents analysis results of a novel grid-connected photovoltaic system using low-voltage high-current system. The electrical energy produced by the photovoltaic system was sent into the electrical power grid using two or more H-bridge current source inverters operated in parallel. The proposed system is very suitable for large size photovoltaic system because of its some merits. The inverter circuits work generating sinusoidal output currents and controlling the power delivered into the grid. The test results of the new system showed that the system worked properly as interface between photovoltaic system and the electrical grid delivering high ac current with low harmonic distortion
\end{abstract}

Copyright (c) 2019 Institute of Advanced Engineering and Science. All rights reserved.

\section{Corresponding Author:}

Suroso,

Department of Electrical Engineering,

Jenderal Soedirman University,

Mayjen Sungkono St. km. 5, Purbalingga, Central Java, Indonesia.

Email: suroso.te.unsoed@gmail.com

\section{INTRODUCTION}

Generation of electrical energy must be improved both quantity and their service quality in order to comply the needs of consumers. The electric power plants can use fossil fuels or renewable energy resources for instance: geothermal power, wind power, solar, water and ocean waves as the main energy sources. However, because of environment reasons, the renewable energy sources are better choice to solve problems incurred by the conventional power plants [1-4]. In case of renewable power generation, solar power plant is a renewable power plant utilizing sunlight as its energy source to produce electricity. This power plant uses photovoltaic modules to convert the sunlight radiation become electricity.

The PV system usually be operated as stand-alone system, hybrid system or grid connected system $[5,6]$. The stand-alone PV system is commonly applied for remote regions where the utility power network is not available. In the hybrid PV system, the PV system is operated together with conventional power plant such as diesel power generation or with other renewable energy systems such as wind power, geothermal, fuel-cell and hydro power systems. In case of PV systems operated in a grid tied system, the PV system is tied to the power grid to supply the electricity to the load together with utility power system. In this system, power inverter is requisite to proceed and to control the generated electrical power to meet the voltage and frequency of utilities [7,8]. The power inverters can be either voltage or current source type inverters $[9,10]$. Voltage source type inverters have been commonly available in the market, and used widely in the PV power generation. The current source type inverter is an alternative for PV power converter with its features such as its reliability, better quality of output current, ease of power control and more immune to the power grid voltage fluctuations [11,12]. 
The electrical energy generated by a photovoltaic (PV) system relies on some environmental factors, as intensity of solar energy or sunlight radiation, the position angle of sunlight, and the weather condition. Moreover, the reliability and efficiency of the power converter, power quality, solar cell or PV module efficiency and the losses incurred in other electrical components will affect the performance of PV system [13-15]. Parasitic resistances in a PV module are a cause of PV losses. Even parasitic resistance values are small, connecting many PV modules in series will raise the total losses of PV system [16-19]. To increase the quality and reliability of electrical energy output, new concepts are absolutely necessary to be created especially for the PV power system.

In this research article, a novel system of grid connected PV system using current source type inverter is presented. The system is designed for a low-voltage high-current PV systems to maximize the advantages of PV systems and inverter. Operation and performance of the new system were examined in laboratory by using computer simulations. Some test results and analysis of the new PV system are discussed to explore the achievements and features of the new system.

\section{PROPOSED SYSTEM}

Figure 1 presents the suggested photovoltaic power generation system. In this figure, the system consist of two PV systems with two inverters and two power transformers operated in parallel. For a larger PV system size, the system can be extended with more power inverters and transformers. The photovoltaic system will convert the sunlight energy become electrical energy in the form of dc voltage. This dc power is converted by the power inverter to be sinusoidal ac current and voltage. The inverter works also to control the electrical power that will be inserted into the electrical grid. The power transformers step-up the inverter's output voltage to match the power grid voltage and as galvanic isolation.

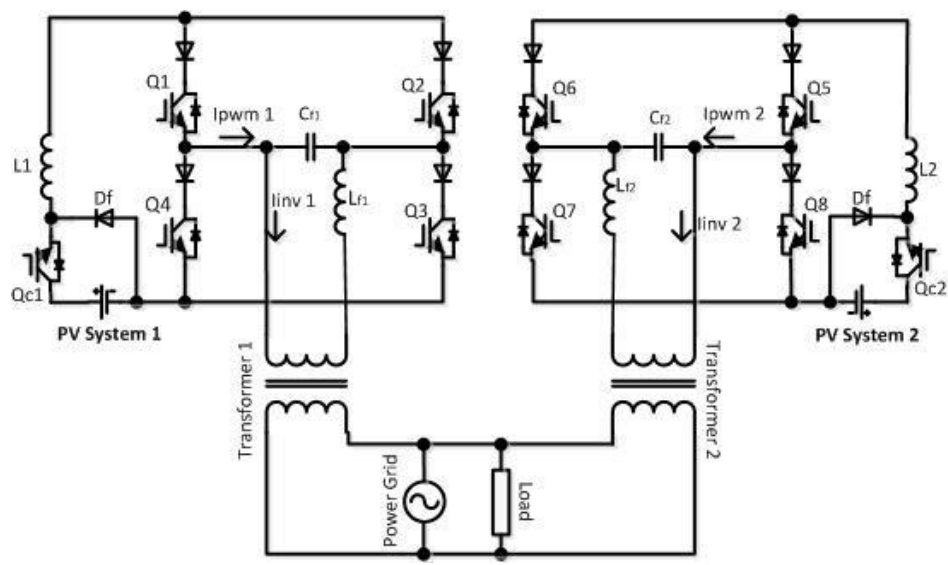

Figure 1. Proposed PV-inverter system

To build the photovoltaic system, this research used PV module from KYOCERA Solar manufacturer, i.e. Kyocera KD325 series. Table 1 shows the Kyocera KD325 series specs of PV module used in the system. Parallel PV modules were employed to obtain higher dc input current for the power inverter circuits. In this system, two photovoltaic array systems were used. One PV array system was constructed by six PV modules as indicated in Figure 2. Each PV array system is tied to the electrical grid via a single $\mathrm{H}$-bridge current-source type inverter. Hence, total two inverters were used. It is also possible to apply more inverters for higher PV power system.

Table 1. Photovoltaic module specification

\begin{tabular}{ll}
\hline Parameters & Value \\
\hline Maximum power & $325 \mathrm{~W}$ \\
Maximum voltage peak power $\left(\mathrm{V}_{\mathrm{mpp}}\right)$ & $40.3 \mathrm{~V}$ \\
Open circuit voltage $\left(\mathrm{V}_{\mathrm{OC}}\right)$ & $49.7 \mathrm{~V}$ \\
Maximum current $\left(\mathrm{I}_{\mathrm{max}}\right)$ & $8.07 \mathrm{~A}$ \\
Short circuit current $\left(\mathrm{I}_{\mathrm{sc}}\right)$ & $8.69 \mathrm{~A}$ \\
\hline
\end{tabular}




\subsection{Power inverter circuits}

The power inverter circuits used in this PV system are the H-bridge current source type inverters as presented in Figure 1. A single inverter is composed of four controlled power switches serially connected with power diode in order to obtain bidirectional power switch [20], [21]. An important property of currentsource type inverter is the ON / OFF sequence of all IGBT switches. This sequence will determine the quality of output current and voltage of the inverter circuits. For current-source type inverter, an open-circuit state is highly avoided, since high voltage generated by the dc-link inductor can occur and it can damage the switching devices [22-25].

A passive LC low pass filter was installed at the output terminal of inverter circuit to filter the harmonic components of the inverter's current and to produce a sinusoidal load current from the three-level PWM output current. Each inverter is connected to a power transformer which has winding ratio 1:6. The transformer serves as a galvanic insulation among the PV system and the electrical grid. It functions also to protect the inverter from the damage in consequence of the faults occurred at the electrical grid side [26]. The dc power source consists of some PV modules joined in parallel as depicted in Figure 2. At the PV output terminal, a filter capacitor is placed, because the DC output voltage of the PV modules still have a large enough ripple, hence the capacitor was required that serves as a filter to minimize the ripples of PV's current and voltage waveforms.

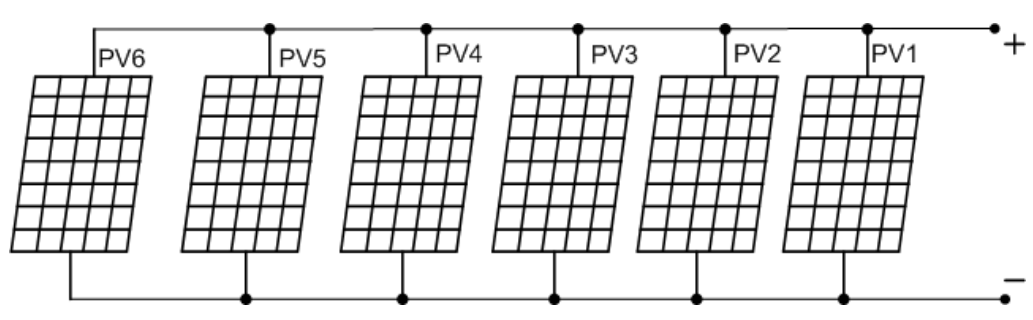

Figure 2. PV array system

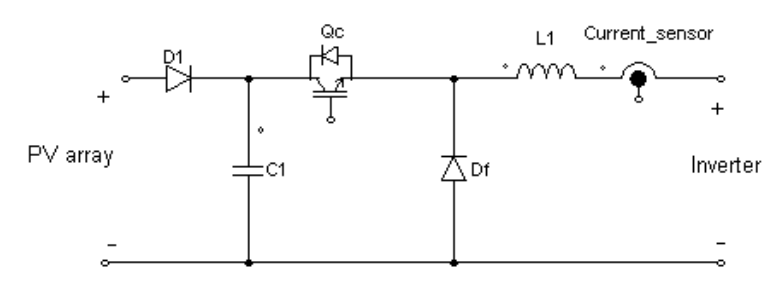

Figure 3. Control circuits of DC current source

\subsection{Control circuits of DC current source}

The DC current control circuits used to produce the DC currents as inputs of the power inverter is described in Figure 3. The circuits is composed of an IGBT $\left(\mathrm{Q}_{c}\right)$ as a controlled semiconductor switch, diode $\left(D_{f}\right)$, inductor and current sensor. The switch used in this circuits is an IGBT. Based on Figure 3, the PV array is used as the dc power supply of the control circuits and power inverter, the diode $\left(\mathrm{D}_{1}\right)$ functions to prevent current not flowing back into PV system, capacitor $\left(C_{1}\right)$ serves as ripple filter of PV output voltage. The current detector is used to detect and to regulate the current of the PV system to obtain a stable and constant dc current [27], [28].

When the switch Qc is at $\mathrm{ON}$ condition, the inductor $\mathrm{L}_{1}$, capacitor $\mathrm{C}_{1}$, and the power load will be connected to the voltage source (PV Array). This condition is called ON state. The freewheeling diode $\left(D_{f}\right)$ will work in reverse bias under this conditions. If the switch Qc is turned-OFF, the borne magnetic energy in the power inductor is transfered to the power load. The freewheeling diode $\left(\mathrm{D}_{\mathrm{f}}\right)$ works in conducting mode.

A proportional-integral (PI) current regulator was applied to regulate the inductor currents. The gating signal of the Qc switch is obtained from the ratio of the current signal flowing thru the current detector and the instruction signal of current controller. The error was modulated to the triangle waveform to generate pulse width signals of the Qc switch. The PI control serves as a reference value of the dc current generator circuits and current magnitude flowing in inductor $\left(L_{1}\right)[29,30]$. 


\section{RESULTS AND DISCUSSION}

In order to attest the feats of the new developed PV system, some computer experiments were done by using power electronic simulation software of PSIM. The system as presented in Figure 1 was tested using test parameters as presented in Table 2. The two photovoltaic systems were tested under different output currents by varying the current magnitude flowing through the inductors of the dc current control circuits. It will simulate the real operation of PV system under different condition of sunlight radiations. In addition, the operation test under the same reference values of inverter current were also performed.

Table 2. Test parameters

\begin{tabular}{ll}
\hline Parameters & Values \\
\hline Inductor of dc current generator circuits & $2.2 \mathrm{mH}$ \\
PV output voltage & $\pm 49.7 \mathrm{~V}$ \\
PV capacitor filter & $10 \mathrm{mF}$ \\
Power grid voltage & $220 \mathrm{~V}$ \\
ON/OFF frequency of IGBT & $22 \mathrm{kHz}$ \\
Inverter output capacitor filter & $100 \mu \mathrm{F}$ \\
Inverter output inductor filter & $1 \mathrm{mH}$ \\
Power load & $R=8, L=6 \mathrm{mH}$ \\
Fundamental inverter's frequency & $50 \mathrm{~Hz}$ \\
Winding ratio of transformer & $1: 6$ \\
\hline
\end{tabular}

Figure 4 shows the output current and voltage at transformer primary side of the first photovoltaic system at 20 A output current operation. The first inverter's current ripples were obviously appeared in this condition. Furthermore, Figure 5 presents the output current and voltage wave shapes of the second photovoltaic system at $50 \mathrm{~A}$ output current operation. It can be viewed that a less ripple of AC output current and voltage waveforms was generated at the 50 A operation. Figure 6 (a) and (b) depict the spectra of harmonics of the first and second inverter's AC output current at $20 \mathrm{~A}$ and $50 \mathrm{~A}$, respectively. Lower harmonic components were acquired for the current magnitude $50 \mathrm{~A}$ of second inverter.

The measured total harmonic-distortion (THD) of AC current occurring in the secondary side of transformer for the first PV system was $4.38 \%$. This value was relatively higher than the total harmonic distortion of the current occurred in secondary side of transformer of the second PV system which was $0.79 \%$. Figure 7 presents a comparison of harmonic orders generated by the first and second inverters under $20 \mathrm{~A}$ and $50 \mathrm{~A}$ output current operations. Mostly, in the PV system generating a lower output current operation, the harmonics components were larger.

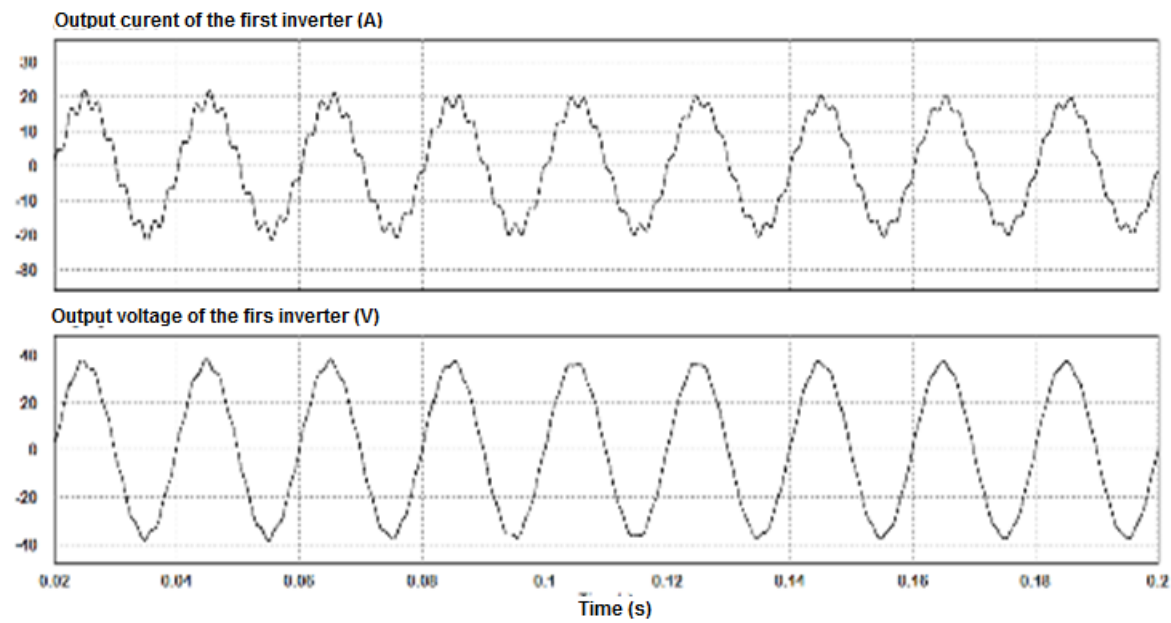

Figure 4. Current and voltage waves of the first inverter at 20 A current operation 

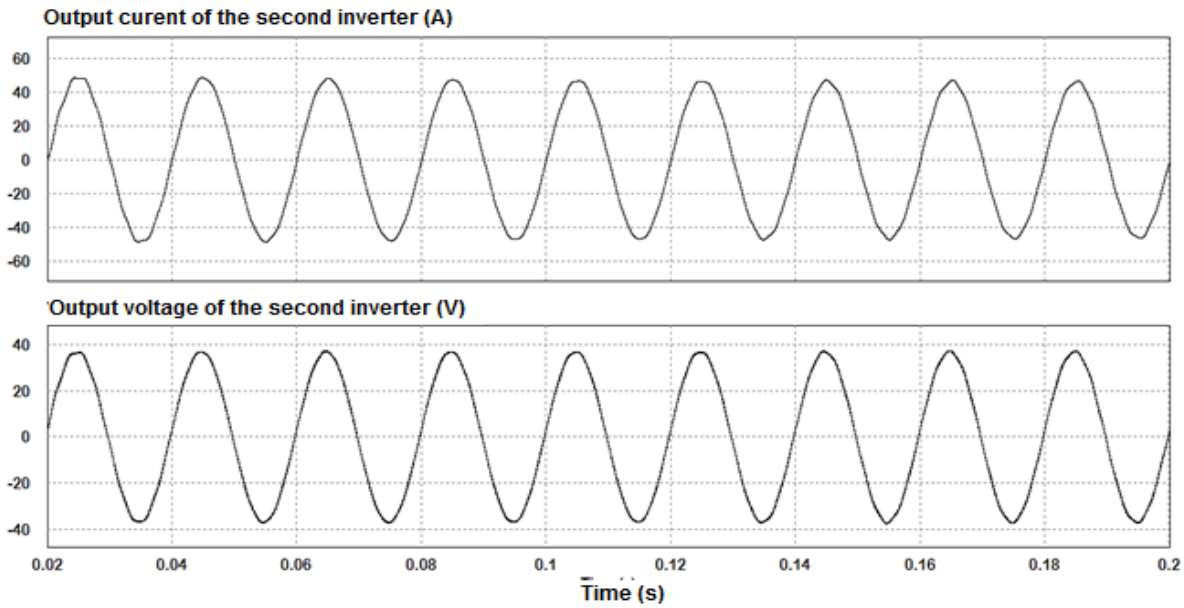

Figure 5. Current and voltage waves of the second inverter at 50 A current operation

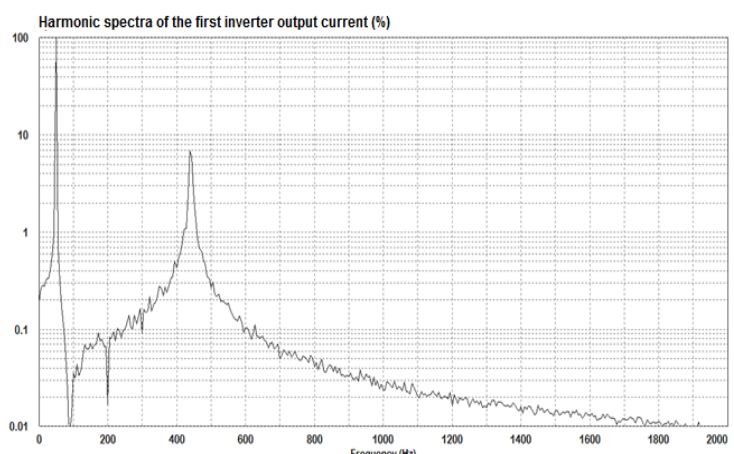

(a)

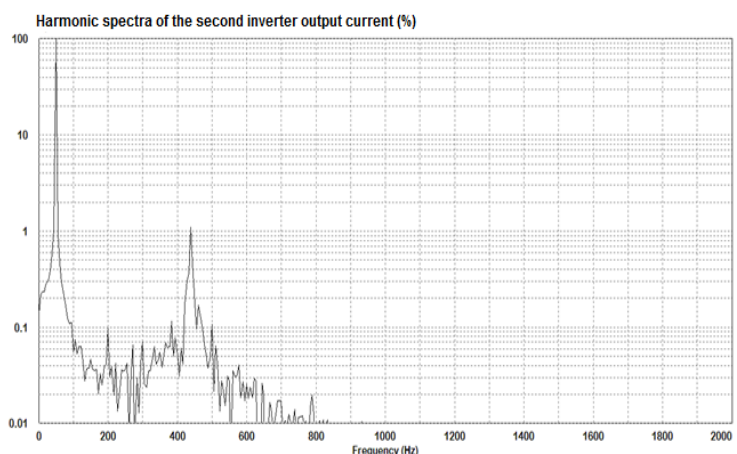

(b)

Figure 6. (a) Harmonics spectra of the first inverter current at 20 A operation,

(b) Harmonics spectra of the second inverter current at 50 A operation

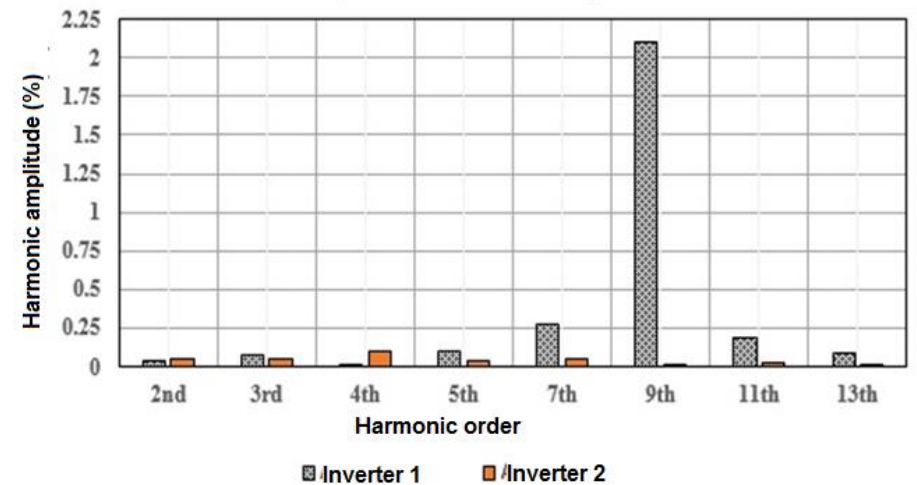

Figure 7. Harmonic current comparison between the first and second inverter at $20 \mathrm{~A}$ and 50 A output current operation

Furthermore, Figure 8 and Figure 9 show the current and voltage waveforms of PV system under the same current operation, i.e. 50 ampere. The harmonic spectra of the first and second inverter systems at $50 \mathrm{~A}$ output current operation are presented in Figure 10 (a) and (b). The harmonic components of both inverter 
currents are almost the same. The THD value of these currents waveforms is $1.35797 \%$ as shown in Figure 11 (a) and (b). Moreover, Figure 11 (c) Denotes the THD value trend of both inverter output currents, when the inverters were operated at the same output currents $20 \mathrm{~A}, 30 \mathrm{~A}, 40 \mathrm{~A}$ and $50 \mathrm{~A}$. The THD values of both inverter current waveforms are the same in these conditions. The higher the inverter output current, the THD values are decreasing.

The magnitudes of inverter's output currents were controlled by adjusting the reference values of the PI current controller and varying the modulation index values of the inverter's pulse-width modulation (PWM) strategy. Figure 12 (a) and (b) Exhibit the effect of varying the inverter modulation index to the THD values of the currents flowing through the primary and secondary sides of the both power transformers. It can be seen in this result that the minimum THD value of the currents were achieved at modulation index 0.9. The over modulation index operation at 1.1 increased the THD value of current waveform.

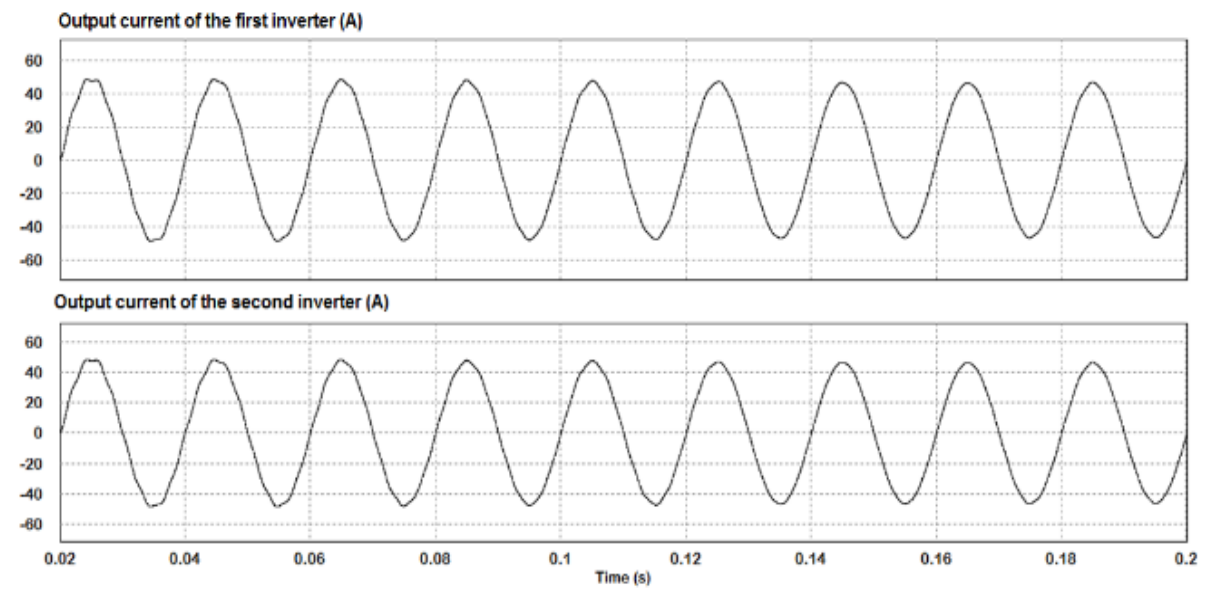

Figure 8. Output current waveforms of the first and second PV systems at 50 A operation

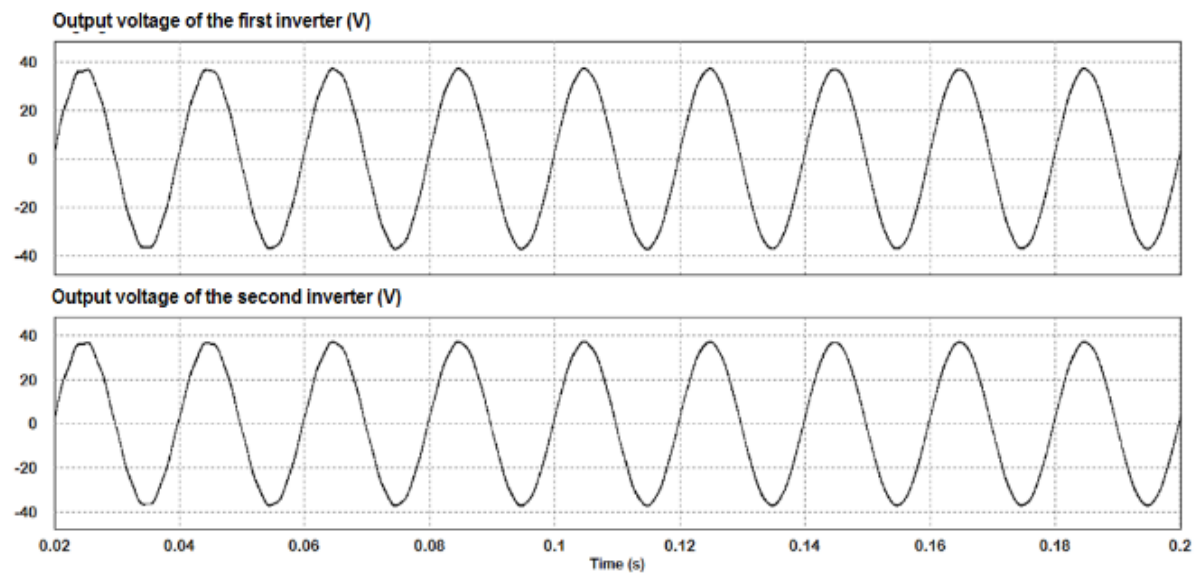

Figure 9. Output voltage waveforms of the transformer primary side of the first and second PV systems at 50 A current operation 


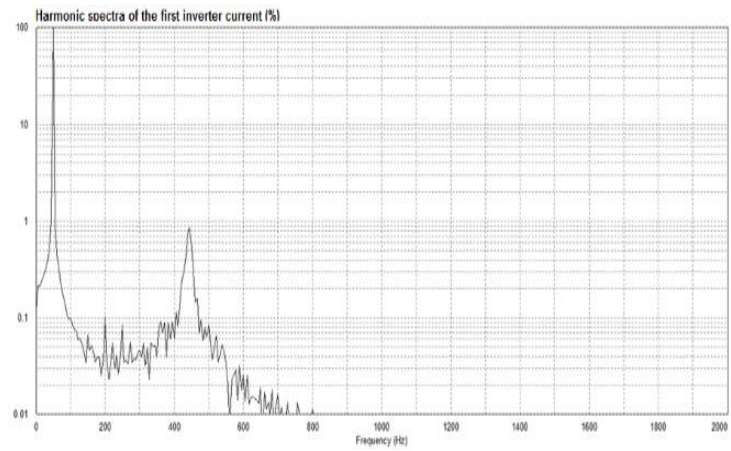

(a)

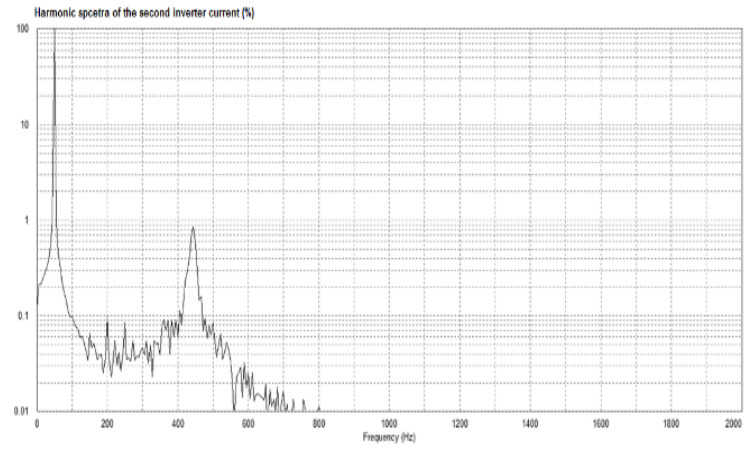

(b)

Figure 10. (a) Harmonics profile of the first inverter current at 50 A operation,

(b) Harmonics profile of the second inverter current at 50 A operation

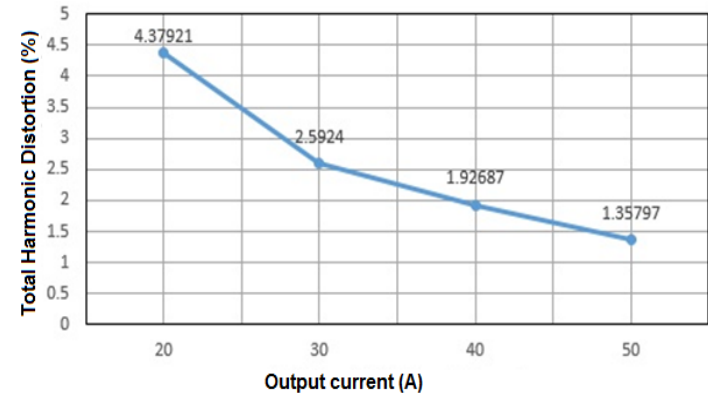

(a)

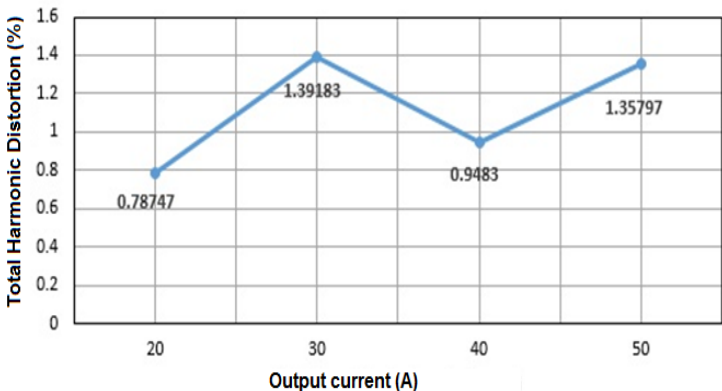

(b)

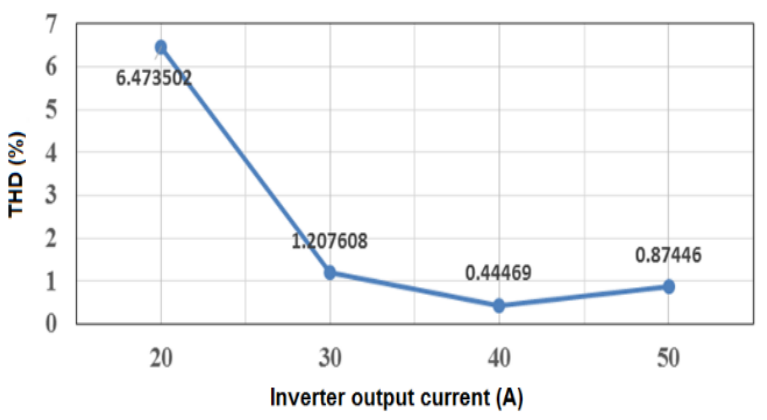

(c)

Figure 11. (a) Relation between the THD value and current magnitude of the first inverter for different output current operation of the first and second PV systems, (b) Relation between the THD value and current magnitude of the second inverter for different output current operation of the first and second PV systems, (c) Relation between the THD and current magnitude of the first and second PV system for the same current operation 


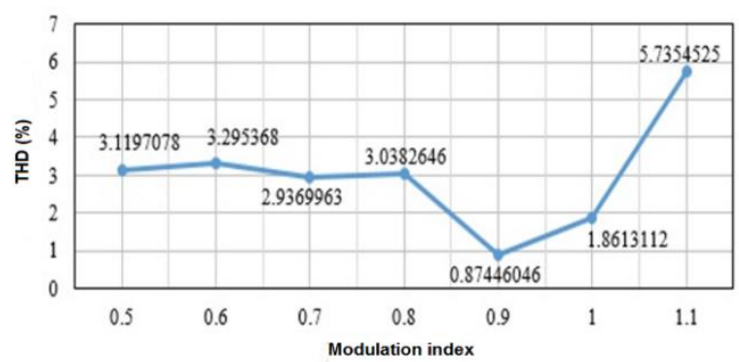

(a)

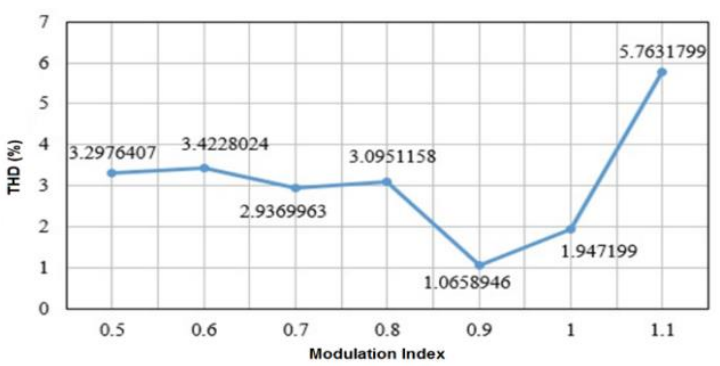

(b)

Figure 12. (a) Relation between inverter modulation index and THD of transformer's primary side current, (b) Relation between inverter modulation index and THD of transformer's secondary side current

\section{CONCLUSION}

This paper discussed a novel low-voltage high-current system for photovoltaic power generation. The proposed system utilized two or more H-bridge current source type inverters operated in parallel. Some new merits can be obtained using the proposed system such as a lower total resistance of the PV system and better quality of inverter's output current. Some computer test results showed that at a higher output power operation, a lower distortion of inverter's AC output current could be achieved by using the proposed system. The PV systems operating at the same inverter output current will have a better performance compare to the inverter systems with different output current operation.

\section{REFERENCES}

[1] K. Kurohane, A. Uehara, T. Senjyu, A. Yona, N. Urasaki, T. Funabashi, and C. Kim, "Control strategy for a distributed DC power system with renewable energy," Renewable Energy, vol. 36, issue 1, pp. 42-49, 2011.

[2] J. M. Carrasco, L.G. Franquelo, Bialasiewicz, J.T., and Alfonso, N.M, "Power-electronics systems for the grid integration of renewable energy sources: a survey," IEEE Transactions on Industrial Electronics, vol. 53, pp. 10021016, 2008.

[3] S. S. Rao, and B. K. Murthy, "A new control strategy for tracking peak power in a wind or wave energy system," Renewable Energy, vol. 34, issue. 6, pp. 1560-1566, 2009.

[4] Chong H. Ng, M. A. Parker, L. Ran, P. J. Tavner, J. R. Bumby, and E. Spooner, "A multilevel modular converter for a large, light weight wind turbine generator," IEEE Transactions on Power Electronics, vol. 23, no. 3, pp. 1062$1074,2008$.

[5] Kjaer, S. B., Pedersen, J. K. and Blaajerg, F., "A review of single phase grid connected inverters for photovoltaic modules," IEEE Transactions on Industry Application, vol. 41, pp. 453-462, 2005.

[6] P. G. Barbosa, H. A. C. Braga, M. C. Barbosa, and E. C. Teixeria, "Boost current multilevel inverter and its application on single phase grid connected photovoltaic system," IEEE Transactions on Power Electronics, vol. 21, pp. 1116-1124, 2006.

[7] Chun-hua $\mathrm{Wu}$, "Topology for current-source grid-connected inverter with improved efficiency and pulse width modulation control strategy," Journal of Shanghai University, vol. 12, pp. 554-559, December 2008.

[8] J. Rodiguez, J. S. Lai, and F. Z. Peng, "Multilevel inverter: a survey of topologies, controls, and application," IEEE Transactions on Industrial Electronics, vol. 49, pp. 724-738, 2002.

[9] Suroso, A. N. Aziz, and T. Noguchi, "Five-level PWM Inverter with a Single DC Power Source for DC-AC Power Conversion," International Journal of Power Electronics and Drive Systems (IJPEDS), vol. 8, pp. 1230-1237, September 2017.

[10] Suroso, D. T. Nugroho, A. N. Azis, and T. Noguchi. "Simplified five-level voltage source inverter with level-phase shifted carriers based modulation technique," Indonesian Journal of Electrical Engineering and Computer Science, vol. 13, no. 2, pp. 461-468, 2019

[11] R. T. H. Li, H. S. Chung, and T. K. M. Chan, "An active modulation technique for single-phase grid connected CSI," IEEE Transactions on Power Electronics, vol. 22, pp.1373-1380, 2007.

[12] Suroso and T. Noguchi, "A new three-level current-source PWM inverter and its application for grid connected power conditioner," Energy Conversion and Management, vol. 51, issue 7, pp. 1491-1499, 2010.

[13] C. L. Shen, and S. T. Peng, "A half-bridge PV system with bi-direction power flow controlling and power quality improvement," $7^{\text {th }}$ International Conference on Power Electronics and Drive Systems, pp. 725-731, 2007.

[14] K. Tabaiya, W. Lenwari, and C. Prapanavarat, "A single-phase grid-connected inverter using a boost two-cell switching converter with maximum power point tracking algorithm," $5^{\text {th }}$ International Conference on Electrical Engineering/Electronics, Computer, Telecommunications and Information Technology, pp. 1001-1004, 2008. 
[15] S. R. Mohamed, P. A. Jeyanthy, and D. Devaraj, "Hysteresis-based voltage and current control techniques for grid connected solar photovoltaic systems: comparative study," International Journal of Electrical and Computer Engineering (IJECE), vol. 8, no. 5, pp. 2671-2681, October 2018.

[16] N. Mutoh, M. Ohno, and T. Inoue, "A method for MPPT control while searching for parameters corresponding to weather conditions for PV generation systems," IEEE Transactions on Industrial Electronics, vol. 53, no. 4, pp. 1055-1065, 2006.

[17] J. M. Enrique, E. Dura'n, M. Sidrach-de-Cardona, and J. M. Andu'jar, "Theoretical assessment of the maximum power point tracking efficiency of photovoltaic facilities with different converter topologies," Solar Energy, vol. 81, pp. 31-38, 2007.

[18] G. Saikrishna, S. K. Parida and R. K. Behera, "Effect of parasitic resistance in solar photovoltaic panel under partial shaded condition," International Conference on Energy Systems and Applications (ICESA), pp. 396-401, 2015.

[19] Dhass. A. D, Lakshmi. P, and Natarajan. E, "Investigation of performance parameters of different photovoltaic cell materials using the Lambert-W function," Energy Procedia, vol. 90, pp. 566-573, 2016.

[20] T. Noguchi, and Suroso, "Review of novel multilevel current-source inverters with H-bridge and common-emitter based topologies," IEEE Energy Conversion Congress and Exposition, pp. 4006-4011, 2010.

[21] Suroso, and T. Noguchi, "Multilevel current waveform generation using inductor cells and H-bridge current source inverter," IEEE Transactions on Power Electronics, vol. 27, no.3, pp. 1090-1098, 2012.

[22] Suroso, Daru T. N., and Winasis, "A three-level common-emitter current source inverter with reduced device count," $4^{\text {th }}$ International Conference on Information Technology, Computer, and Electrical Engineering (ICITACEE), pp. 73-76, 2017.

[23] T. Noguchi, and Suroso, "New multilevel current-source PWM inverter with full-bridge inductor cells," IEEJ Transactions on Industry Applications, vol. 130, pp. 808-815, 2010.

[24] Z H. Bai, and Z. C. Zhang, "Conformation of multilevel current source converter topologies using the duality principle," IEEE Transactions on Power Electronics, vol. 23, pp. 2260-2267, September 2008.

[25] D. Xu, N.R. Zargari, B. Wu, J. Wiseman, B. Yuwen, and S. Rizzo, "A medium voltage AC drive with parallel current source inverters for high power application," in Proceeding of IEEE PESC, pp. 2277-2283, 2005.

[26] Suroso, H. Prasetijo, D. Trinugroho, and T. Noguchi, "A new five-level current source PWM inverter for grid connected photovoltaics", in Proceeding of CITEE, pp. 98-103, 2012.

[27] Suroso, and T. Noguchi, "New H-bridge multilevel current-source PWM inverter with reduced switching device count," in Proceeding of IEEE IPEC, pp. 1228-1235, 2010.

[28] Suroso, and T. Noguchi, "Five-level common-emitter inverter using reverse-blocking IGBTs", Telkomnika (Telecommunication Computing Electronics and Control), vol.10, pp. 25-32, March 2012.

[29] Suroso, D.T. Nugroho and Winasis, "Three-level common-emitter current source power inverter with simplified dc current source generation," Journal of Engineering Science and Technology, vol. 13, no.2, pp. 4027-4038, 2018.

[30] Suroso, and T. Noguchi, "Common-emitter topology of multilevel current-source pulse width modulation inverter with chopper based DC-current sources," IET Power Electronics, pp. 759-766, 2011.

\section{BIOGRAPHIES OF AUTHORS}

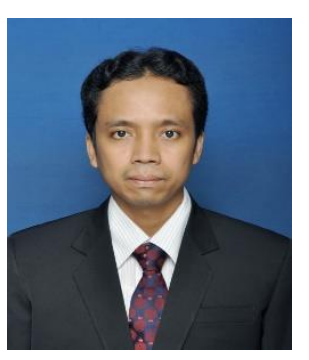

Suroso received the B. Eng. degree in electrical engineering, from Gadjah Mada University, Indonesia in 2001, and the M. Eng. degree in electrical and electronics engineering from Nagaoka University of Technology, Japan in 2008. He was a research student at electrical engineering department, Tokyo University, Japan from 2005 to 2006. He earned the Ph.D degree in energy and environment engineering department, Nagaoka University of Technology, Japan in 2011. He was a visiting researcher at electrical and electronics engineering department, Shizuoka University, Japan from 2009 to 2011. Currently, He is an associate professor at department of electrical engineering, Jenderal Soedirman University, Indonesia. His research interest includes power converters, and its application in renewable energy conversion system.

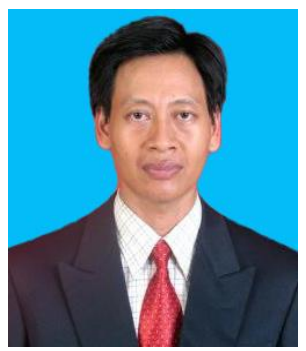

Daru Tri Nugroho received bachelor (B.Eng.) degree in electrical engineering from Institute Teknologi Sepuluh November, Surabaya, Indonesia and M.Eng. degree in electrical engineering from Universitas Indonesia. Currently $\mathrm{He}$ is a lecturer in Electrical Engineering Department, Jenderal Soedirman University. His research interests are power electronics and renewable energy system. 


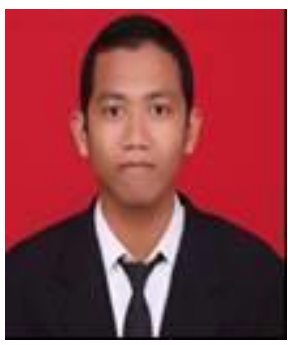

Amran was born in 1991. He was a student at Electrical Engineering Department, Jenderal Soedirman University.

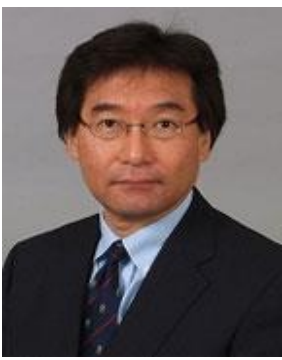

Toshihiko Noguchi was born in 1959. He received the B. Eng. degree in electrical engineering from Nagoya Institute of Technology, Nagoya, Japan, and the M. Eng. and D. Eng. degrees in electrical and electronics systems engineering from Nagaoka University of Technology, Nagaoka, Japan, in 1982, 1986, 1996, respectively. In 1982, he joined Toshiba Corporation, Tokyo, Japan. He was a Lecturer at Gifu National College of Technology, Gifu, Japan, from 1991 to 1993 and a Research Associate in electrical and electronics systems engineering at Nagaoka University of Technology from 1994 to 1995. He was an Associate Professor at Nagaoka University of Technology from 1996 to 2009. He has been a Professor at Shizuoka University since 2009. His research interests are static power converters and motor drives. Dr. Noguchi is a Member of the IEE-Japan and a Senior Member of the IEEE. 